\title{
Evaluation and comparison of affinity chromatography and precipitation- based methods on purification of recombinant streptokinase
}

\author{
Masoud Seyedinkhorasani ${ }^{1}$, Malihe Keramati ${ }^{2}$, Reza Ahangari Cohan ${ }^{3}$, Farzin Roohvand $^{4}, \underline{\text { Dariush Norouzian }}^{5}$ \\ 1 PhD Student of Pharmaceutical Biotecnology, Nano-biotechnology Department, Pasteur Institute of Iran (PII), \\ Tehran, Iran \\ ${ }^{2}$ Assistant Professor, PhD of Pharmaceutical Biotechnology, Nano-biotechnology Department, Pasteur Institute of Iran \\ (PII), Tehran, Iran \\ ${ }^{3}$ Associate Professor, PhD of Pharmaceutical Biotechnology, Nano-biotechnology Department, Pasteur Institute of \\ Iran (PII), Tehran, Iran \\ ${ }^{4}$ Associate Professor, PhD of Medical Biotechnology, Virology Department, Pasteur Institute of Iran (PII), Tehran, \\ Iran \\ ${ }^{5}$ Professor, PhD of Biochemistry, Nano-biotechnology Department, Pasteur Institute of Iran (PII), Tehran, Iran
}

\begin{abstract}
Background: Increase of protein purity is a serious challenge in the production of recombinant therapeutic proteins. For this purpose, several strategies have been employed to purify the target protein, among which the affinity chromatography-based purification methods and tagged proteins such as Ni-NTA are common and but costly. Therefore column-free purification techniques, such as using elastin-like proteins (ELPs), are being developed as alternative method. In present study, the efficacy of Ni-NTA, ELP, and the combined NiNTA/ELP was evaluated for purification of streptokinase as a model protein at lab scale.

Materials and methods: Streptokinase gene was amplified by PCR, cloned into pET21-ELP, and transformed into E.coli BL21 Rosetta cell. The expressed protein was then purified using the methods described above. The identity and purity of the protein were evaluated by western blot using Anti-His antibody and SDS-PAGE, respectively. The purification yield was also calculated for each method by microBradford assay.

Results: The purification yield was calculated as $76 \pm 16 \mu \mathrm{g} / \mathrm{ml}$ in ELP precipitation, $108 \pm 14 \mu \mathrm{g} / \mathrm{ml}$ in NiNTA purification and $88 \pm 11 \mu \mathrm{g} / \mathrm{ml}$ in Ni-NTA/ELP combined method, respectively. The SDS-PAGE results showed that the purity of streptokinase purified by the combined method was higher than that of each method separately.

Conclusion: The present study showed that the integration of purification methods in one step can increase the purity and yield in purification process of recombinant therapeutic proteins.

Keywords: ELP, Elastin like polypeptide, Protein purification, Column-free purification, Streptokinase.

Cited as: Seyedinkhorasani M, Keramati M, Ahangari Cohan R, Roohvand F, Norouzian D. Evaluation and comparison of affinity chromatography and precipitation - based methods on purification of recombinant streptokinase. Medical Science Journal of Islamic Azad University, Tehran Medical Branch 2020; 30(4): 387-395.
\end{abstract}

Correspondence to: Malihe Keramati \& Dariush Norouzian

Tel: +9802164112168

E-mail: keramatim@pasteur.ac.ir \& dnsa@pasteur.ac.ir

ORCID ID: 0000-0002-7196-8751 \& 0000-0002-9597-3555

Received: 1 Sep 2019; Accepted: 6 Feb 2020 
مجله علوم يزشكى دانشگاه آزاد اسلامى

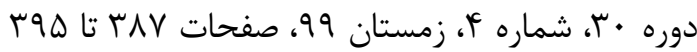

Original

Article

\title{
بررسى و مقايسه روشهاى مبتنى بر رسوب دهى و كروماتوكرافى تمايلى در تخليص يروتئين نوتركيب استر يتوكيناز
}

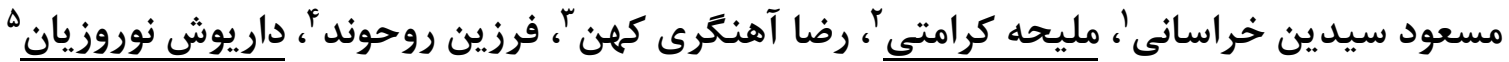

\author{
دانشجوى دكترى تخصصى بيوتكنولوزى دارويى، انستيتو ياستور ايران، بخش نانوبيوتكنولوزى، تهران، ايران

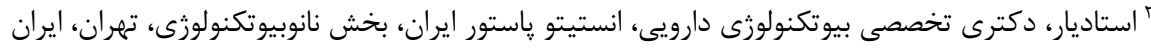

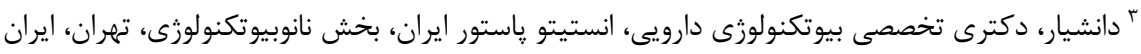

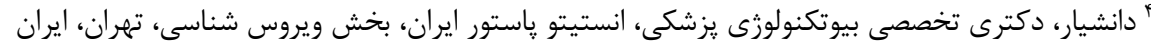

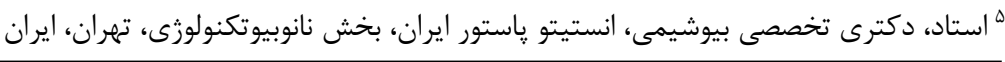

جكبده

سابقه و هدف: تخليص بروتئين با بازده و خلوص بالا جالشى جدى در تهيه بروتئين هاى نوتركيب دارويى /ست. /ز بين /ستراتثىهاى تخليص

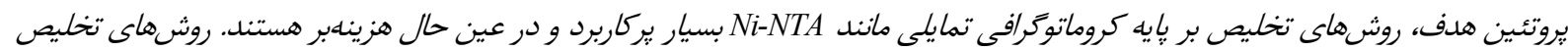

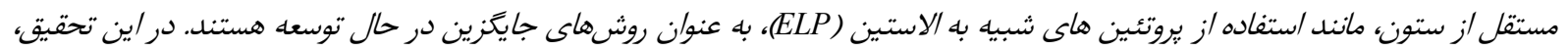

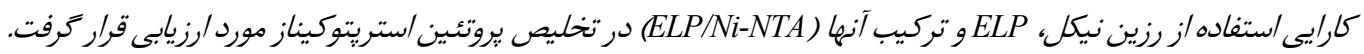

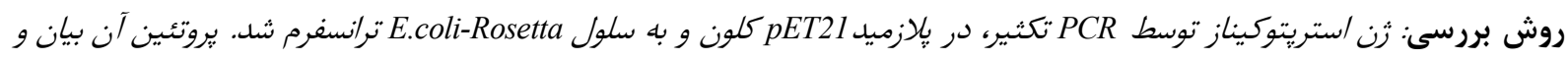

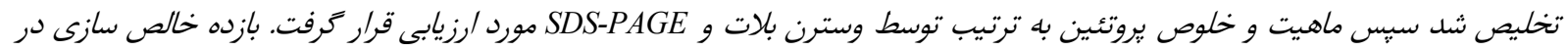

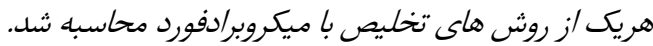

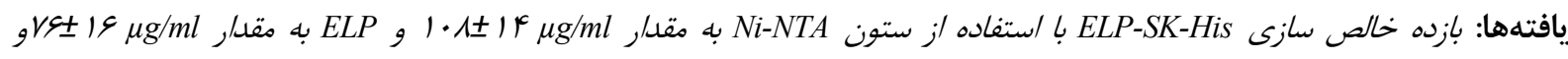

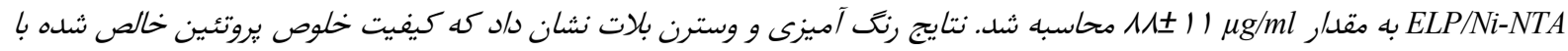

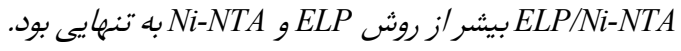

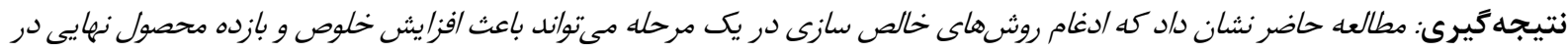

$$
\text { توليد بروتئينهاى نوتركيب دارويى شون. }
$$

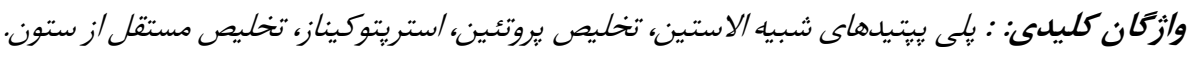

خلوص و بيشترين فعاليت بيولوزيكى براى بسـيارى از مطالعـات

مقدمه

بيولوزيكى و كاربردهاى درمـانى ضـرورى اسـت. در صـنعت نيـز بيشترين هزينه توليـد يـك محصـول بـهـ جداسـازى و تخلـيص

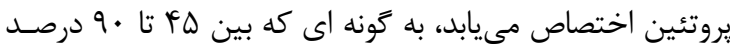
هزينه فرآيندهاى يايين دستى را به خود اختصاص مئ مدهد (1).

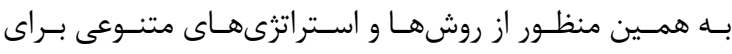
تخليص يروتئين هـدف از سـاير يـروتئينهـاى غيراختصاصسى و رون

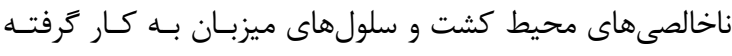

جداسازى و تخليص يروتئين يك فرآينـد اساسـى و مـورد نيـاز

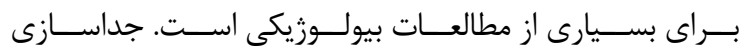
يروتئينهاى مطلوب با بيشترين مقدار ممكـن، بـالاترين ميـزان

آدرس نويسنده مسئول: تهران، خيابان پياستور، انستيتوياستور ايران، بخش نانوبيوتكنولوزّى، مليحه كرامتى،

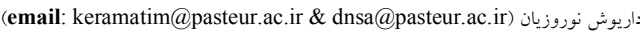
ORCID ID: 0000-0002-7196-8751 \& 0000-0002-9597-3555

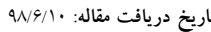

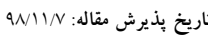


ييروى مى كنند. در اين ساختار n تعداد تكرار هـاى يــنج اسـيد

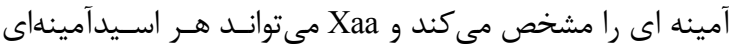

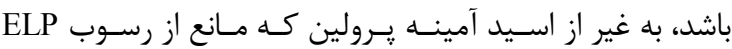

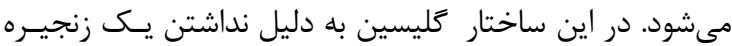
جانبى بزرگ باعث مىشود بيويليمر انعطاف يذير باشد و يـرولين

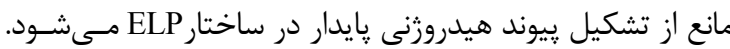

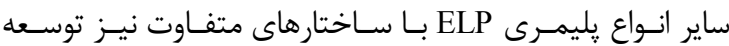
يافتهاند كه در توالى تكرار شونده خود مانــد (IPGVG) و يـا در

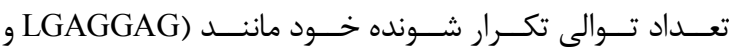
(LGAGGAGVL متفاوت هستند. به دمايى كه ELP از حالـت محلول به حالت نامحلول در مىآيد، دماى كذار كَتــه مسىشـود (Tt)، به گونهاى كه در دماى بالاتر از دماى كذار نامحلول و در دمـاى يـايينتــر از دمـاى گَذذار ELP بــه صـورت محلول است. همجنين اين دما به واسطه ماهيت يروتئين متصل شده به ELP و آب گريزى و باردار يا بدون بار بودن اسيد آمينــه جايگاه Xaa متغير خواهد بود (ساه بـ - (1). در تحقيـق حاضــر يــروتئين Streptokinase (SK) از بــاكترى Streptococcus equisimilis

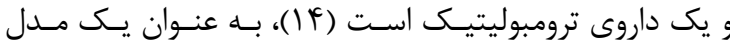
(Val-Pro-Gly-Xaa- ELP بـا سـاختار

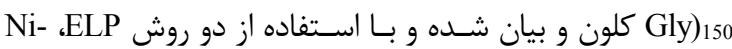
NTA هر كدام از اين روشها در مقدار يروتئين تخليص شده و كيفيت خلوص محصول نهايى مورد ارزيابى قرار گرفت.

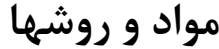

ساخت سازههاى زنى

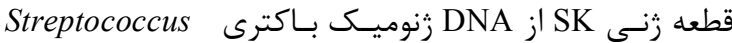
equisimilis ATTC 9542 اختصاصى (جدول () تكثير شد و ريس از برش با آنزيمههـاى XhoI Department of Chemical and ‘David Wood Biomolecular Engineering, The Ohio State (University, Columbus, Ohio شكل l نشان داده شده است، زن SK در جايخَـاه انتهـاى

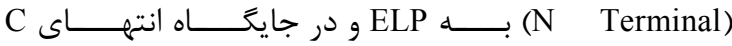

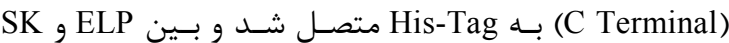
جايڤًاه بـرش آنزيمسى بــراى آنـزيم يروتئساز FactorXa قـرار

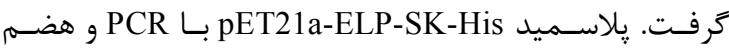

مىشود تا با كمترين هزينه به بيشترين مقدار محصول نهايى بـاـ

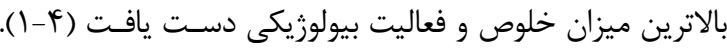

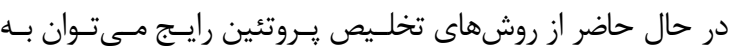

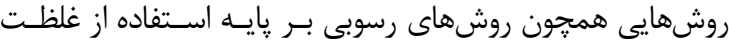

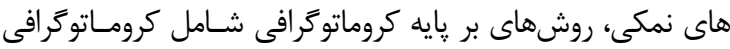

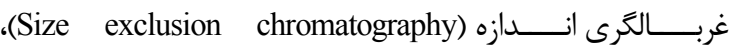

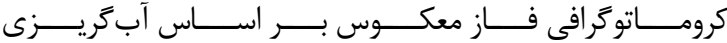
Ion exchange (كروماتو گرافى تعـويض يـونى (Hydrophobicity)

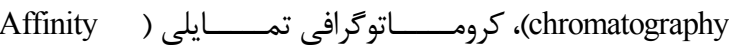

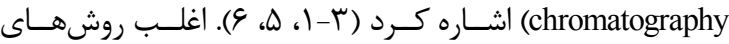

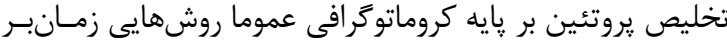

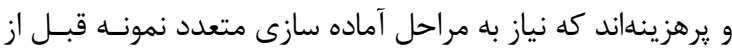
فرآيند تخليص دارند (Y, V). با اين وجود كرومـاتوگرافى تمـايلى به دليل اختصاصيت در بسيارى از يروتكـلهـــى خـالص سـازى

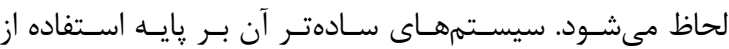

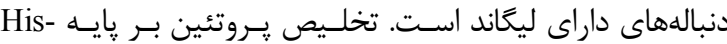

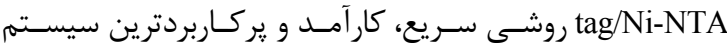

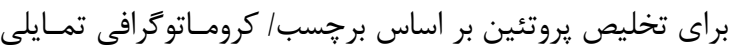

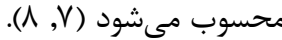
تخليص يروتئين بر يايه His-tag/Ni-NTA علسىرغسم سـادگى و

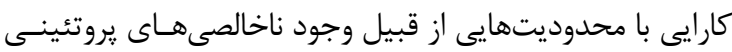

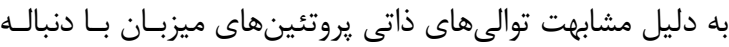
هيستيدينى نيز روبرو است. بنابراين توسعه روشهاى نوين و يـا تركيبى روشهايى جهت كارامـدى مـوثرتر روش سـاده و قابـل دسترسى مانند His-tag/Ni-NTA ضرورى به نظر مىرسد (N). يلى يֶُتيدهاى شبيه به الاستين (ELPs) بيويليمرهاى مصنوعى

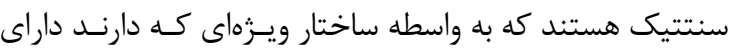

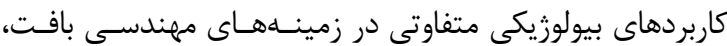
درمان سرطان، دارورسانى و تخليص يروتئين هستند. اصلىترين

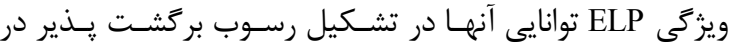

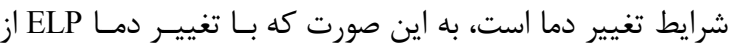
ساختار مارييج هـاى محلـول در آب بـهـ رسـوب هـاى نـامحلول تغيير وضعيت مىدهد (ه, 9). از همين ويزگَى تشـكيل رسـوب

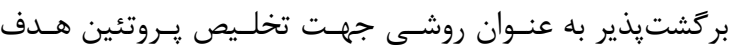
استفاده شده است. بدين ترتيب كه با اتصال يـروتئين هــدف بـهـ

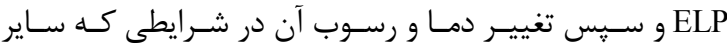
يروتئينهاى موجود به صورت محلول هستند، يروتئين هدف بـا

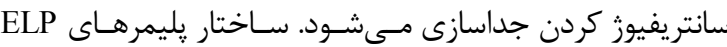
رايج داراى يك ساختار تكرار شونده ينج اسيد آمينه هستند كــهـ

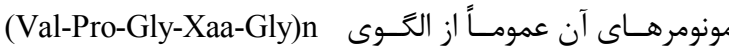


PBS Imidazole حاوى 800mM Imidazole يروتئينهـاى متصـل بـه سـتون

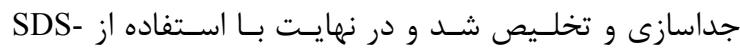
PAGE ميكرو برادفورد مورد ارزيابى قرار گرفت. تخليص يروتئين با استفاده از Ni-NTA/ELP يس از تخلـيص ELP-SK-His بـا اسـتفاده از سـتون حـاوى رزين Hi-NTA كه به واسطه His-Tag انجـام شـد. محصـول تخليص شده بـهـ واسـطه ELP متصـل بــهـ آن بـا اسـتفاده از

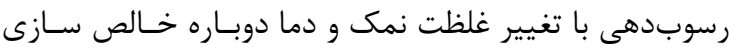

شد.

\section{SDS-PAGE}

به منظور ارزيابى كيفيت تخليص در هر سه روش، الكتروفورز

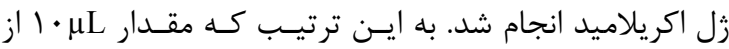

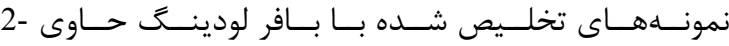
mercaptoethanol 1 . SDS-PAGE كماسى بلو (G250)انجام شد. تعيـين هويـت يـروتئين هــاى تخليص شده با وسترن بلات و استفاده از آنتى بادى كونزوگَه ( HRP-Conjugated anti-His-tag monoclonal antibody)

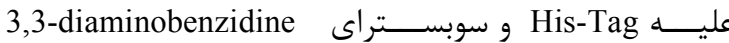
(DAB)

غلظت سنجـى يــروتئين بــا تســت ميكـــرو برادفــورد (Micro-Bradford assay) تست برادفـورد طبـق تروتكـلهــــ اسـتاندارد و بــا اسـتفاده از آلبومين سرم گاوى BSA (bovine serum albumin) بـهـ عنـوان

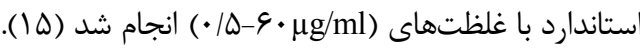

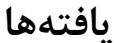

نتايج تاييد زن SK كلون شده در pET21a-ELP با هضم آنزيمى و PCR همان طور كه در شكل r نشان داده شده است يلاسميد pET21a-ELP-SK-His هضم آنزيمى تاييد شد. باند 1261bp تكثير رن SK توسط PCR با يرايمر هاى اختصاصى جدول I را نشان مى

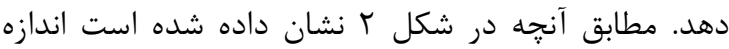
pET21a- قطعات برش خورده شده حاصل از هضم آنزيمى ELP-SK-His را تاييد كرد. SK
آنزيمى توسط آنزيم هاى NdeI و XhoI تاييد شد (شـكل r). سيس با استفاده از شوك حرارتى در بـاكترى E.coli BL21 Rosseta (DE3) (Invitrogen TM) كلونى هاى مطلوب با استفاده از يليـت حسـاوى محـيط كشـت 2XYT و آنتى بيوتيكى آميسى سـيلين بـا غلظـــ نهـايى 50

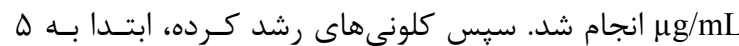

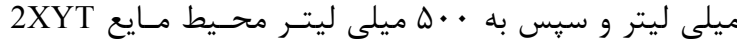
حاوى آنتى بيوتيك آميى سيلين

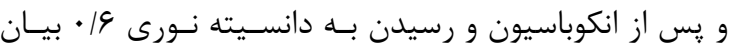
يروتئين توسط IPTG با غلظـت نهـايى \ • القـاء شـد. باكترىهاى القاء شده به مدت 19 ساعت در دماى بr درجه

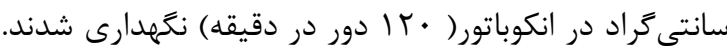

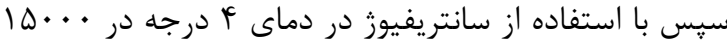
دور در دقيقه باكترى هاى القاء شده رسوب گيرى شدند. تخليص :برو تئين ELP-SK-His بــا اســتفاده از تغييــر غلظت نمك و تغيير دما

phosphate ) PBS توده باكتريايى رسوب داده شـده در بـافر (buffered saline سونيكاسيون بـه مـدت ها دقيقـه ( Amplitude 60, 15 sec (on, 30sec off

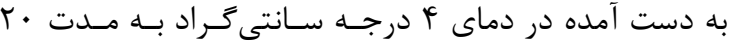
دقيقه در •ها دور در دقيقه سانتريفيوز شد. مـايع رويسى

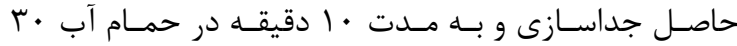
درجه همزده شد. سيس محلول نمك NaCl با غلظت DM تا زمان نمايان شدن رسوبات ابرى شـكل نـامحلول بـهـ صـورت

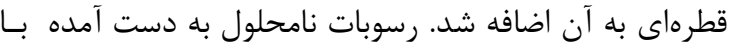

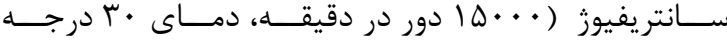

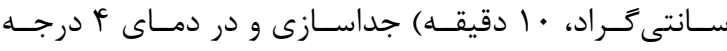
سانتى گراد در بافر PBS حل شد. به منظـــور افـزايش ميـزان خلوص مراحل تخليص ذكر شده تا سه بار تكرار شـد سـيس

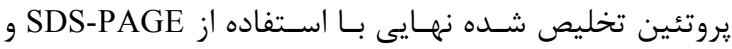

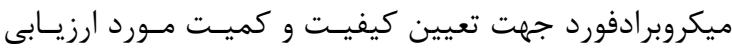

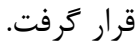

Ni-NTA تخليص يروتئين با استفاده از ستون

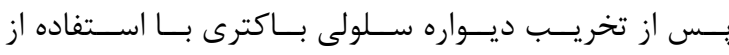
سونيكاسيون (Amplitude 60, 15 sec on, 30sec off) ليزت بون سلولى به دسـت آمـده سـانتريفيوز شـد (15000g, 10min). Ni- سيس محلول رويـى از روى سـتون حسـاوى رزيسن هـاى

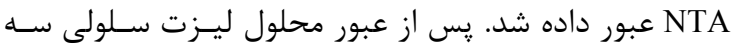
مرحله شستشـو بـا اسـتفاده از Dml بـافر PBS حـاوى mM 
جدول ا. توالى يرايمر هاى تكثير SK

\begin{tabular}{|c|c|c|c|}
\hline 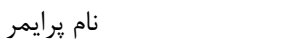 & \multicolumn{3}{|c|}{ توالى يرايمر } \\
\hline R-SK-XhoI & \multicolumn{3}{|c|}{ ATATCTCGAGTTTGTCGTTAGGGTTATCAG } \\
\hline F-SK-EcoRI & \multicolumn{3}{|c|}{ ATAGAATTCATTGCTGGACCTGAGTG } \\
\hline \multicolumn{4}{|c|}{ جدول r. ميزان يروتئين استخراج شده با استفاده از ELP و رزين Ni-NTA } \\
\hline روش تخليص & تخليص اول & تخليص دوم & تخليص سوم \\
\hline ELP-based & $\vee \& \pm 1 \& \mu \mathrm{g} / \mathrm{ml}$ & $\vee \backslash \pm 11 \mu \mathrm{g} / \mathrm{ml}$ & $99 \pm 1 r \mu \mathrm{g} / \mathrm{ml}$ \\
\hline Ni-NTA resin & $1 \cdot \wedge \pm \mid \uparrow \mu \mathrm{g} / \mathrm{ml}$ & - & - \\
\hline Ni-NTA/ELP & $\Lambda \Lambda \pm \| / \mu \mathrm{g} / \mathrm{ml}$ & - & - \\
\hline
\end{tabular}

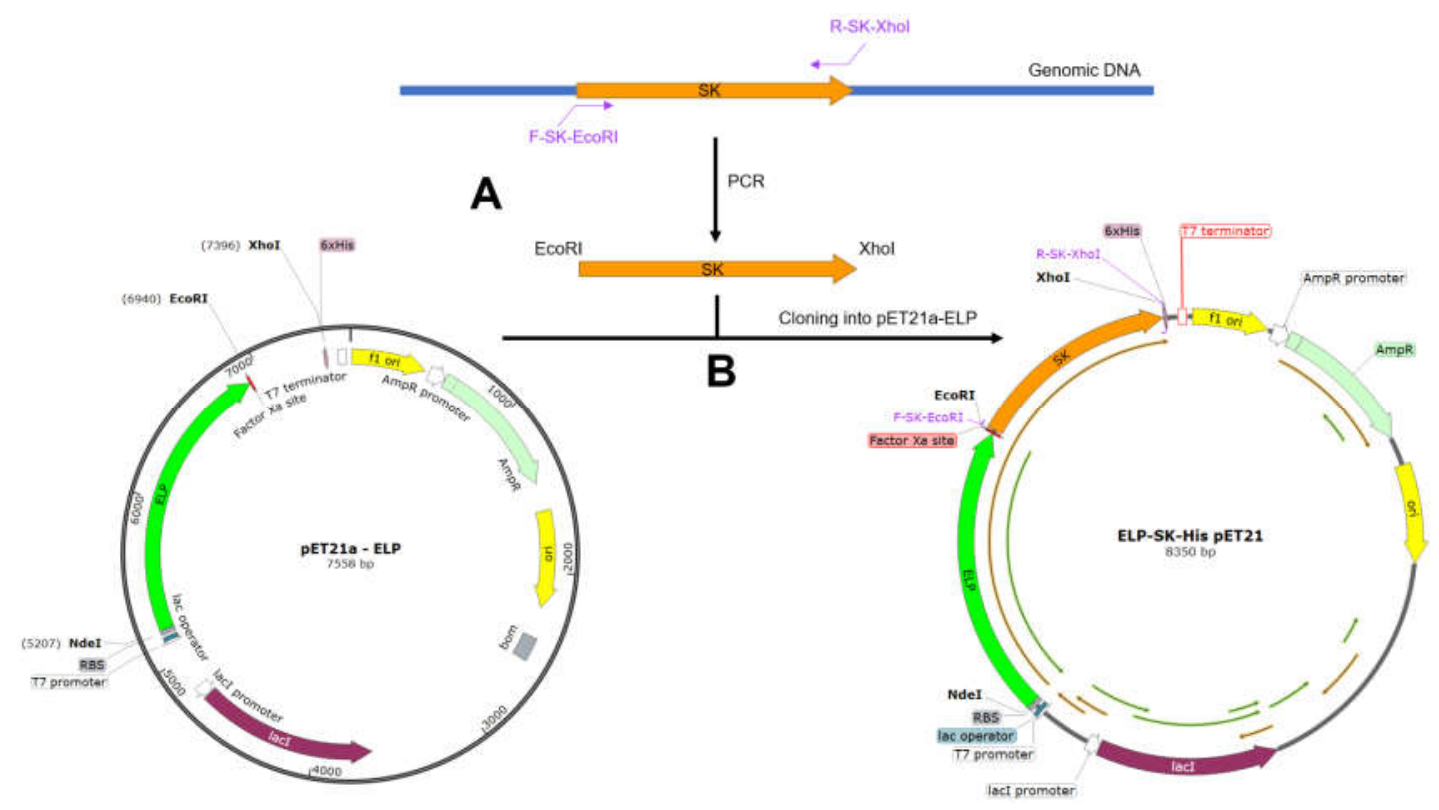

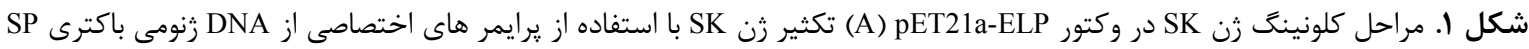

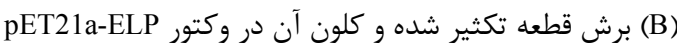

نتايج تخليص يروتئين با استفاده از ستون Ni-NTA و :Ni-NTA/ELP ELP-SK-His شد سيس با استفاده از ELP مراحل خالص سازى بيشتر روى آن انجام شد كه نتايج SDS-PAGE تخليص يروتئين

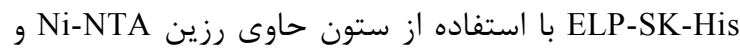
Ni-NTA/ ELP

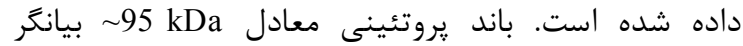

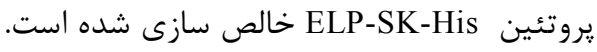

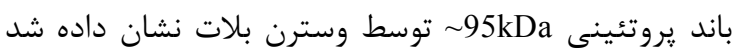
كه بيانكر صحت يروتئين ELP-SK-His تخليص شده با هر دو روش Ni-NTA و ELP است. مقدار يروتئين تخليص شده با استفاده از هر دو روش
نتايج تخليص يروتئين ELP-SK-His با استفاده از تغيير غلظت نمك وتغيير دما شكل ץ نشان دهنده نتايج سه مرحله تخليص با استفاده از تغيير دما و تغيير غلظت نمك NaCl بيانكًر كاهش مقدار

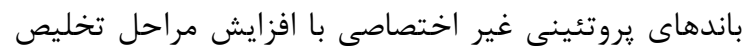
است. همان طور كه در شكل F نشان داده شده است يروتئين ELP-SK-His غلظت نمك NaCl به صورت نامحلول و در دماى أ درجه سانتى كراد و كاهش غلظت نمك NaCl به صورت محلول مشاهده مى شود. 
A

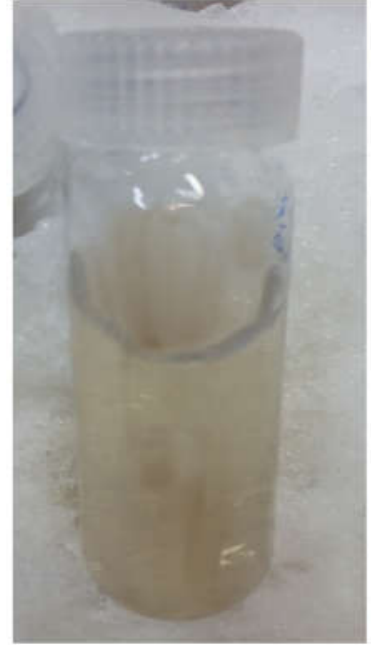

B

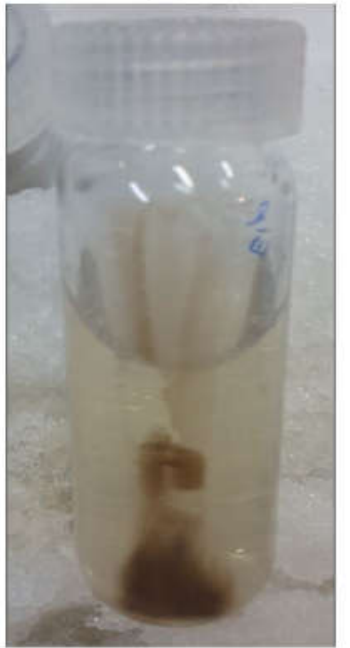

شكل f. تخليص ELP-SK-His با استفاده از دما • ب درجه و نمك (A) NaCl

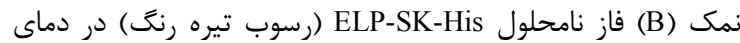

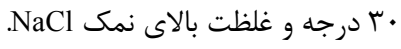

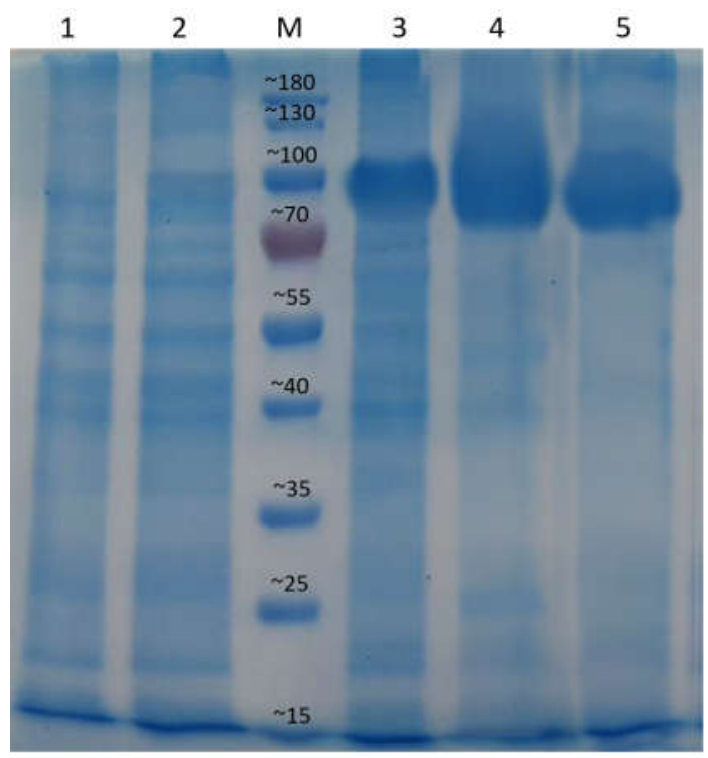

Ni- شكل ه. تخليص يروتئين ELP-SK-His با استفاده از ستون

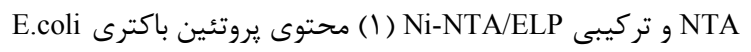
BL21 Rosseta

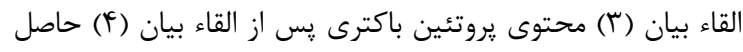

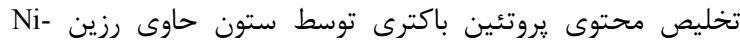

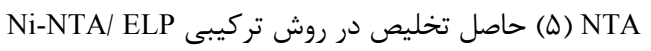

از ميكرو برادفورد سنجيده شد و نتايج آن در Error! Reference source not found.

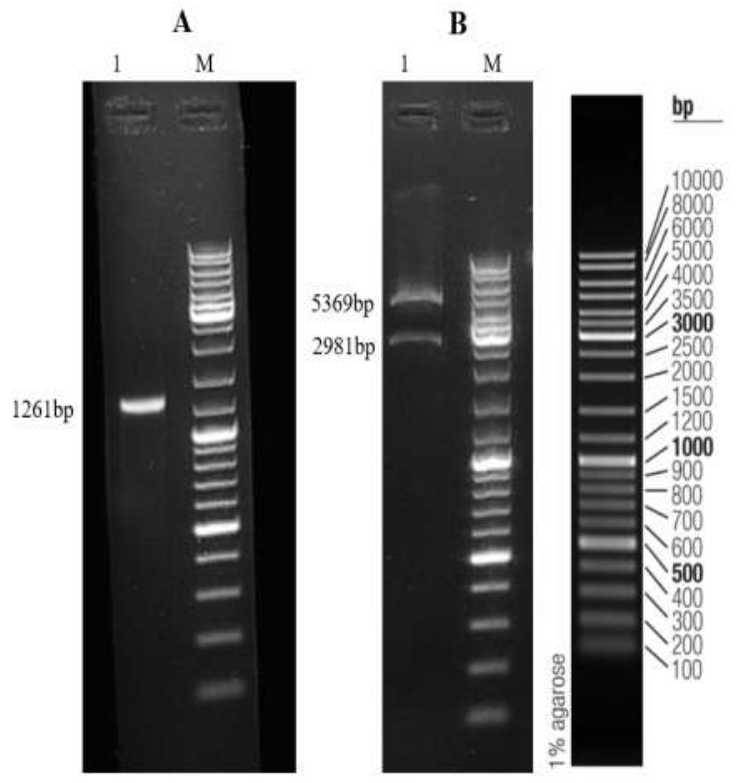

شكل r. نتايج تاييد كلونينگ رن PCR با PK و هضم آنزيمى (A)

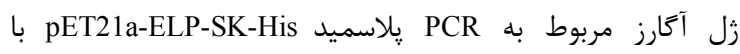
يرايمرهاى اختصاصى جدول I (B) نتيجه هضم آنزيمى پِلاسميد

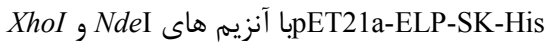

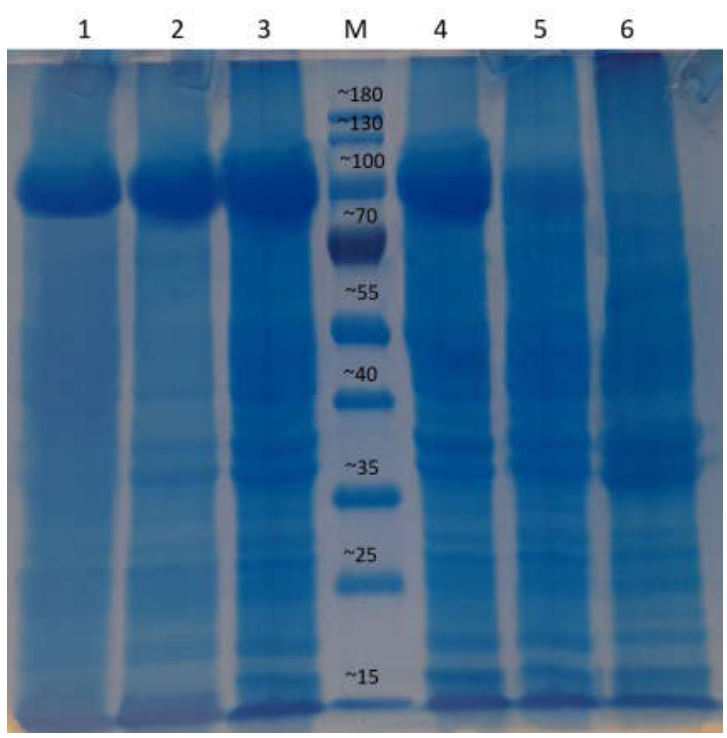

شكل س. تخليص يروتئين ELP-SK-His با استفاده از نمك و دماى

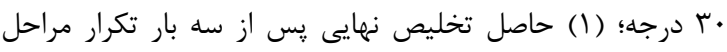
تخليص، (Y) حاصل تخليص نهايى يس از دو بار تكرار مراحل

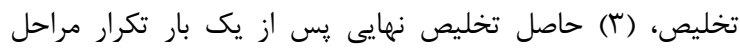

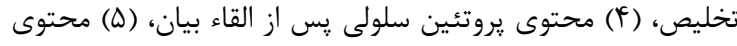

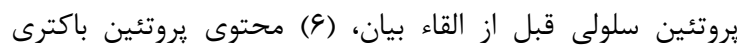
E.coli BL21 Rosseta 
روشهاى تخليص :بروتئين نيز استفاده كرد (9, عا, IV). است را جهت افزايش ميزان خلوص مورد استفاده قرار دادند (ه, 9). در تحقيقى ديكر با متصل كردن يك اينتئين

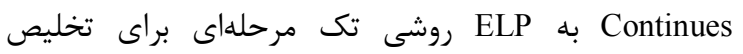

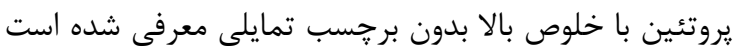

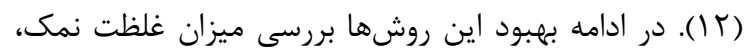

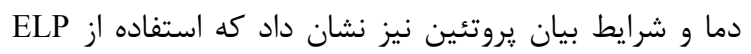

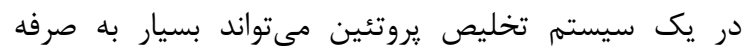

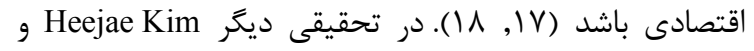

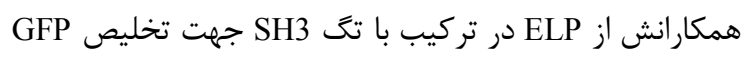

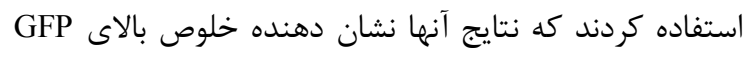

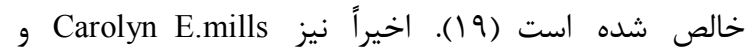

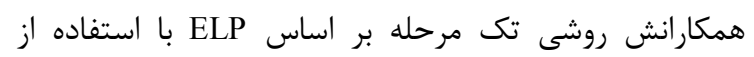

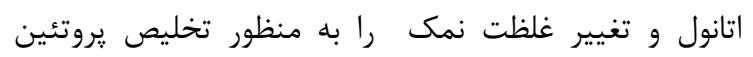

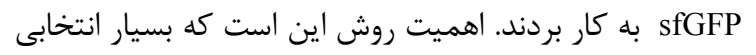

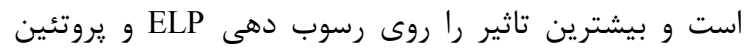

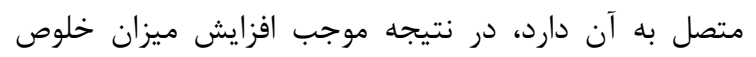

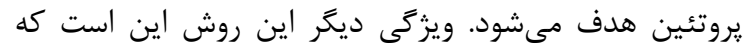

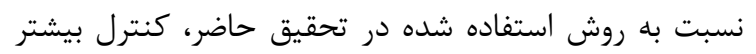

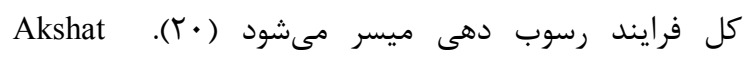

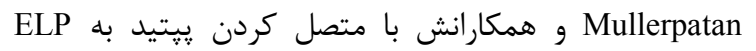

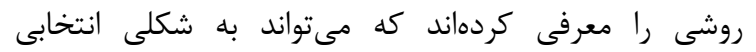

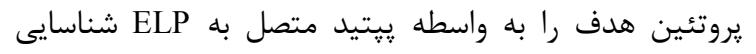

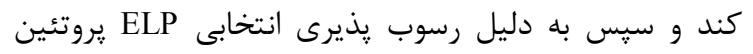

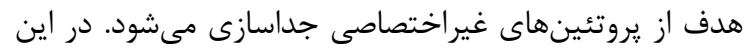

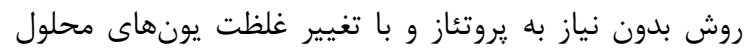

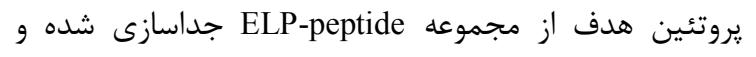

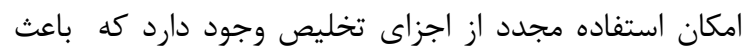

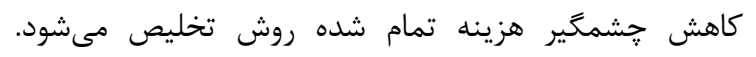

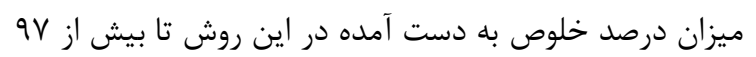

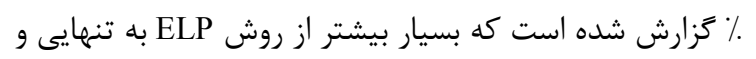

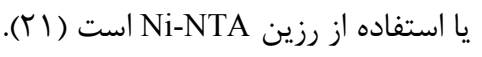

M

$\sim 180$

$\sim 130$

$\sim 100$

$\sim 70$

$\sim 55$

$\sim 40$

$\sim 35$

$\sim 25$

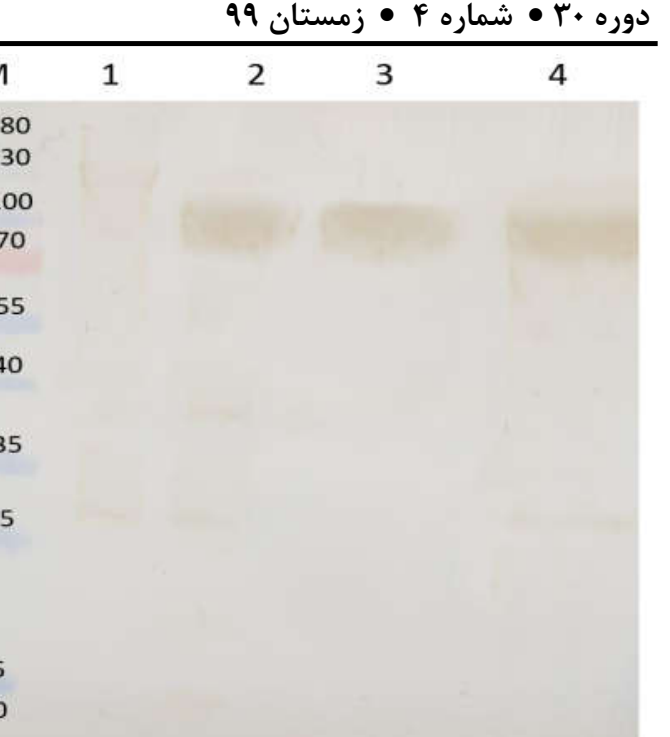

شكل 9. نتايج وسترن بلات محصول نهايى تخليص (1) شحت

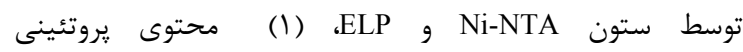

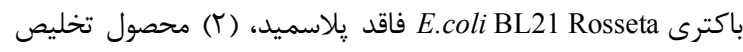
ELP- توسط ستون Ni-NTA ELP-SK-His ELP-SK- توسط Ni-NTA و ELP، (F) محصول تخليص STA His

\section{بحث}

pET21a- در اين تحقيق، ابتدا زن SK با موفقيت در بلاسميد ELP

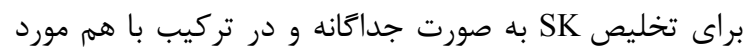

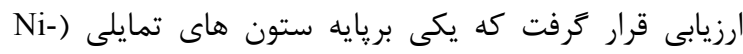

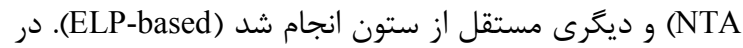
ELP-SK- هردو روش مطالعه حاضر، يروتئين ( 95kDa )

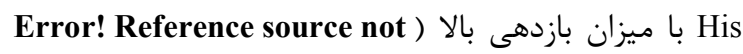
(found. محصول نهايى به دست آمده با استفاده از روش

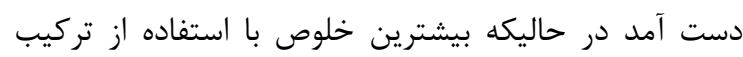

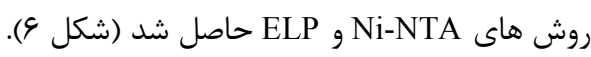
همان طور كه در شكل r نشان داده شده است، با تكرار

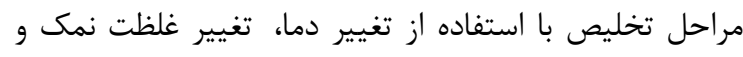

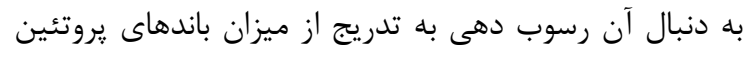

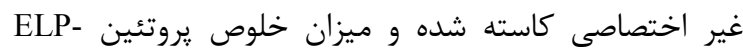

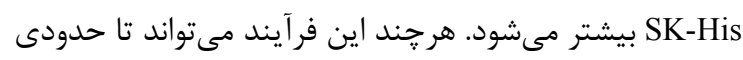

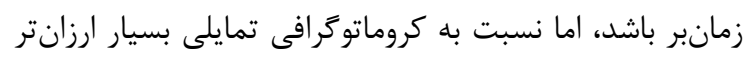

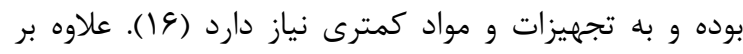

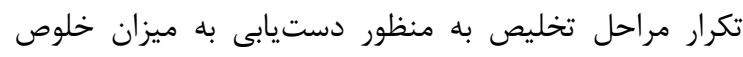

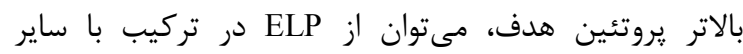


همان طور كه در شكل ا نشان داده شده است، در سازه زنى ELP-SK-His Factor Xaa به منظور جداسازى ELP از SK مورد استفاده قرار كيرد.

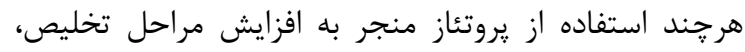
تحميل هزينه هاى اضافى و ايجاد تغيير در محصول نهايى مىشود (TY) كه جهت حل اين مسئله اخيرا يلىيِتيدهاى اينتئين با خاصيت خود برشى به عنوان جايكزين مناسبى إنى

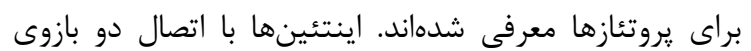
انتهاى C و انتهاى N و اتصال قطعات يلى پِيتيدى از ساختار

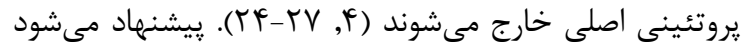

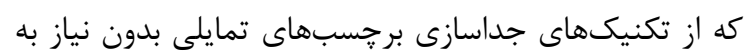
يروتئزازها به مانند روش هاى مبتنى بر اينتئين استفاده كرد. مقايسه دو روش Ni-NTA و ELP در تخليص يروتئين SK در مر مئسين اين تحقيق نشان داد كه بيشترين مقدار يروتئين تخليص شده ده

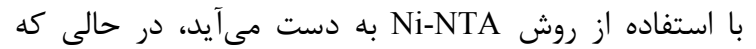
خلوص يروتئين تخليص شده به واسطه ELP و Ni-NTA از

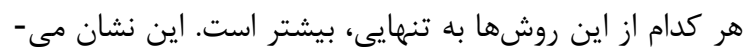
دهد كه تركيب روشهاى ELP و دستيابى به يروتئينهاى با خلوص بالاتر موثرتر از استفاده اين روشها به تنهايى است. بـ برونين

\section{تقدير و تشكر}

بدين وسيله از انستيتوراستور ايران جهت حمايت مالى از اين تحقيق تشكر و قدردانى مىشود.
نتايج وسترن بلات نشان داد كه باندهاى يروتئينى غيراختصاصى بيشترى در محصول نهايى تخليص شده توسط بـ دان

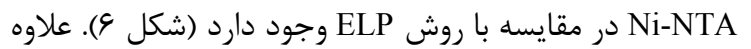
بر اين، نتايج SDS-PAGE تخليص به واسطه Ni-NTA نيز تاييد كننده خلوص بيشتر است (شكل هل ه) كه دليل آن بهل مىتواند اين باشد كه در روش تخليص :روتئين با استفاده از ستون Ni-NTA يروتئينهاى درون سلولى ميزبان نيز مىتوانند به دليل توالىهاى حاوى اسيد آمينه هيستيدين ذاتى به ستون Ni-NTA متصل شوند (Tr). از اين رو به نظر به مىرسد كه تخليص :روتئين به واسطه ELP در مقايسه با روش به ستون Ni-NTA داراى خلوص بيشترى باشد، هرجند

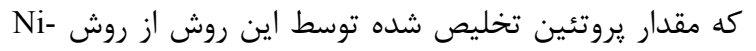
NTA دكتر Akhani و همكارانش نيز به مقايسه تخليص به واسطه

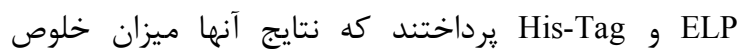
يروتئين آلفا-آميلاز تخليص شده بيشترى در مقايسه با روش

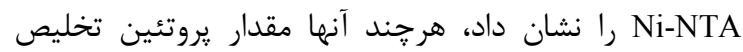
شده بيشترى توسط ELP در مقايسه با Ni-NTA تخليص كردند. نتايج وسترن بلات همجنين نشان داد كه با تركيب روش تخليص ELP با Ni-NTA مىتوان از تخليص همزمان يروتئينهاى غيراختصاصى كه در فرايند تخليص با ستون همراه با يروتئين Ni-NTA جلو گيرى كرد (شكل ؟). در تحقيقى كه Trabbic $\square$ Carlson

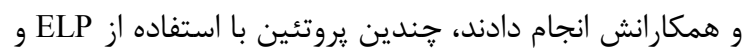

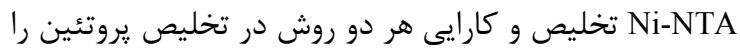
مشابه گزارش كردند. هر جند در مطالعه مذكور تركيب دو

روش ELP و Ni-NTA مورد ارزيابى قرار نگرفته است (Tr).

\section{REFERENCES}

1. Roque ACA, Lowe CR, Taipa MA. Antibodies and genetically engineered related molecules: production and purification. Biotechnol Prog 2004; 20639-54.

2. Gräslund S, Nordlund P, Weigelt J, Hallberg BM, Bray J, Gileadi O, et al. Protein production and purification. Nat Methods 2008; 5:135.

3. Nfor BK, Ahamed T, van Dedem GW, van der Wielen LA, van de Sandt EJ, Eppink MH, et al. Design strategies for integrated protein purification processes: challenges, progress and outlook. J Chem Technol Biotechnol 2008; 83:12432.

4. Arnau J, Lauritzen C, Petersen GE, Pedersen J. Current strategies for the use of affinity tags and tag removal for the purification of recombinant proteins. Protein Expr Purif 2006; 48:1-13.

5. Shi C, Han T-C, Wood DW. Purification of microbially expressed recombinant proteins via a dual ELP split intein system. Methods Mol Biol 2017; 1495:13-25.

6. Block H, Maertens B, Spriestersbach A, Brinker N, Kubicek J, Fabis R, et al. Immobilized-metal affinity chromatography (IMAC): a review. Methods Enzymol 2009; 463:439-73.

7. Cheung RCF, Wong JH, Ng TB. Immobilized metal ion affinity chromatography: a review on its applications. Appl Microbiol Biotechnol 2012; 96:1411-20 
8. Lichty JJ, Malecki JL, Agnew HD, Michelson-Horowitz DJ, Tan S. Comparison of affinity tags for protein purification. Protein Expr Purif 2005; 4:98-105.

9. Shi C, Meng Q, Wood DW. A dual ELP-tagged split intein system for non-chromatographic recombinant protein purification. Appl Microbiol Biotechnol 2013; 97:829-35

10. MacEwan SR, Chilkoti A. Elastin $\square$ like polypeptides: Biomedical applications of tunable biopolymers. J Pept Sci 2010; 94:60-77.

11. Bellingham CM, Lillie MA, Gosline JM, Wright GM, Starcher BC, Bailey AJ, et al. Recombinant human elastin polypeptides self $\square$ assemble into biomaterials with elastin $\square$ like properties. Biopolymers 2003; 70:445-55.

12. Banki MR, Feng L, Wood DW. Simple bioseparations using self-cleaving elastin-like polypeptide tagsNat Methods $2005 ; 2: 659$.

13. Floss DM, Schallau K, Rose-John S, Conrad U, Scheller J. Elastin-like polypeptides revolutionize recombinant protein expression and their biomedical application. Trends biotechnol 2010; 28:37-45.

14. Keramati M, Arabi RM, Memarnejadian A, Mirzaie A, Sazvari S, Aslani MM, et al. Towards a superior streptokinase for fibrinolytic therapy of vascular thrombosis. Hematol Agents Med Chem 2013; 11:218-29.

15. Kruger NJ. The Bradford method for protein quantitation. In: Kruger NJ, Editor. The protein protocols handbook. New Jersey, United States: Humana Press; 2009. P.17-24.

16. Akhani RC, Patel AT, Patel MJ, Dedania SR, Patel JS, Patel DH. Column Chromatography Free Purification of Recombinant $\alpha$-Amylase from Bacillus licheniformis by Tagging with Hydrophobic Elastin Like Polypeptide. Proc Natl Acad Sci India B 2018; 88:1249-55.

17. Fong BA, Wood DW. Expression and purification of ELP-intein-tagged target proteins in high cell density E. coli fermentation. Microb Cell Fact 2010; 9:77.

18. Fong BA, Wu W-Y, Wood DW. Optimization of ELP-intein mediated protein purification by salt substitution. Protein Expr Purif 2009; 66:198-202.

19. Kim H, Chen W. A non-chromatographic protein purification strategy using Src 3 homology domains as generalized capture domains J Biotechnol 2016; 234:27-34.

20. Mills CE, Ding E, Olsen B. Protein Purification by Ethanol-Induced Phase Transitions of the Elastin-like Polypeptide (ELP). Ind Eng Chem Res 2019; 58:11698-709.

21. Mullerpatan A, Chandra D, Kane E, Karande P, Cramer S. Purification of Proteins using Peptide-ELP Based Affinity Precipitation. J Biotechnol 2020; 309:59-67.

22. Bolanos-Garcia VM, Davies OR. Structural analysis and classification of native proteins from E. coli commonly co-purified by immobilised metal affinity chromatography. Biochim Biophys Acta 2006; 1760:1304-13.

23. Trabbic $\square$ Carlson K, Liu L, Kim B, Chilkoti A. Expression and purification of recombinant proteins from Escherichia coli: Comparison of an elastin $\square$ like polypeptide fusion with an oligohistidine fusion. Protein Sci 2004; $13: 3274-84$.

24. Waugh DS. An overview of enzymatic reagents for the removal of affinity tags. Protein Expr Purif 2011; 80:28393.

25. Volkmann G, Mootz HD. Recent progress in intein research: from mechanism to directed evolution and applications. Cell Mol Life Sci 2013; 70:1185-206.

26. Wang B, Luo L, Wang D, Ding R, Hong J. Efficient purification of a recombinant tag-free thermostable Kluyveromyces marxianus uricase by $\mathrm{pH}$-induced self-cleavage of intein and expression in Escherichia coli. 3 Biotech 2018; 8:400.

27. Wu H, Hu Z, Liu X-Q. Protein trans-splicing by a split intein encoded in a split DnaE gene of Synechocystis sp. PCC6803. Proc Natl Acad Sci USA 1998; 95:9226. 